\title{
PRINCÍPIOS DA ELABORAÇÃO DE UM PLANO DE MANUTENÇÃO INDUSTRIAL
}

\author{
ASSIS, K.M., BARRETO, R.F., SILVA, M.M.A., SILVA, M.L.S. \\ Engenharia Mecânica - Centro de Pesquisas, Institutos Superiores de Ensino do CENSA - \\ ISECENSA, Rua Salvador Correa, 139, Centro, Campos dos Goytacazes, RJ, Brasil;
}

Em qualquer tipo de processo industrial é necessário tomar medidas para o bom funcionamento dos equipamentos, tendo em vista a redução das falhas nos equipamentos e a paralização indesejada da produção. Essas paradas indesejadas na produção são vistas com um ponto negativo dentro das finanças da empresa, pois implica em perda de produção. A manutenção é uma das formas utilizadas para solucionar esses problemas. Este trabalho apresenta os tipos de manutenção, sendo a manutenção corretiva, manutenção preventiva e manutenção preditiva, bem com as suas vantagens e desvantagens, o histórico da manutenção e o plano de manutenção criado através de dados coletados em relatórios e em entrevistas com a equipe de manutenção para atender a indústria de exploração mineral. A pesquisa de aplicação foi realizada em maio de 2015, no município de São Fidélis, estado do Rio de Janeiro. Foi adotado um plano de manutenção, com base no número de horas trabalhadas pelos equipamentos e que as manutenções aconteceriam no período da noite, fora do período de produção. Em relação as pesquisas de relatórios, chegou-se aos resultados com relação aos materiais com a manutenção diária: lubrificação da planta, graxa no peneirão, graxa na peneirinha, limpeza dos britadores, complementação dos óleos da redutora, graxa na planta, graxa no britador primário, graxa no britador secundário e graxa no britador terciário. De acordo com as necessidades e limitações da indústria de exploração mineral, o plano de manutenção chegou para atender a estes mesmo pontos citados anteriormente. E por último, relação de troca e serviços baseado na quantidade de horas trabalhadas, troca da tela da peneirinha, troca de tela do peneirão, troca de rolo de carga, troca de rolo do peneirão, troca de rolo do peneirão, troca de mancal do britador, troca de mancal do britador, troca de guia lateral, troca de guia lateral, troca de revestimento, troca de correia, troca da borracha do peneirão e troca da borracha da peneirinha. Conclui-se que entre as manutenções, existe a mais adequada forma para cada equipamento, isto irá variar de acordo com a criticidade da máquina para produção industrial, os custos envolvidos da manutenção e até mesmo do espaço físico da indústria (caso seja necessário grandes estoques). Definir o tipo de manutenção que garante melhor custobenefício não é tarefa simples, mas sem dúvida a definição de criticidade das máquinas é crucial para a correta manutenção, sendo assim, conveniente criar quadros de criticidade dos equipamentos correlacionando o tempo entre falhas que os mesmos possuem.

Palavras-chave: Manutenção, plano de manutenção e exploração mineral.

\section{REFERÊNCIAS}

BARBOSA, R. A. et al. Elaboração e implementação de Um Plano de Manutenção Com Auxílio do 5S: Metodologia Aplicada em uma Microempresa. In: ENEGEP, 29, 2009, Salvador. Anais. Bahia: Sociedade de Engenharia de Produção, 2009. p. 14. 
MALPICA, L. G. T. Manutenção Preditiva de motores de combustão interna, à gasolina, através da técnica de análise de lubrificantes. 2007. 111p. Monografia (Mestrado) - Universidade Estadual Paulista Júlio de Mesquita Filho, São Paulo, 2007.

MARÇAL, R.; SUSIN, A. Detectando Falhas Incipientes em Máquinas Rotativas. Revista Gestão Industrial, Paraná, v.01, n.21, p. 01-10, 2005.

MARCORIN, W. R. ; LIMA, C. R. C. Análise dos Custos de Manutenção e de Não-manutenção de Equipamentos Produtivos. Revista de Ciência e Tecnologia, São Paulo, v.11, nº 22, p. 35-42, 2003.

OTANI, M.; MACHADO, W. V.. A proposta de Desenvolvimento de Gestão da Manutenção Industrial na Busca da Excelência ou Classe Mundial. Revista Gestão Industrial, Paraná, v.04, n.02, p. 01-16, 2008.

PEREIRA. M. J. Engenharia de Manutenção: Teoria e Prática. $2^{\mathrm{a}}$ Edição. Rio de Janeiro: Editora Ciência Moderna LTDA, 2011. 225p.

SANTOS, R.M. Manutenção Mecânica Preventiva dos Equipamentos Móveis: Estudo Realizado Numa Mineradora de Grafite Natural Cristalino. 2012. 45p. Monografia (Bacharel) - Centro Universitário de Formiga, Minas Gerais, 2012.

SILVA, M.L.S. et al. A Importância da Manutenção em Motores Diesel. Perspectivas Online, Rio de Janeiro, v. 03, n. 07, p. 54-61, 2013.

TONDATO, R. Manutenção Produtiva: Estudo Caso na Indústria Gráfica. 2004. 119p. Monografia (Mestrado) - Universidade Federal do Rio Grande do Sul, Porto Alegre, 2004. 